\title{
シリコン表面における酸素吸着の理論
}

\author{
内山 登志弘 \\ 松下技研(株)新素材研究所 函 214 川崎市多摩区東三田 3-10-1
}

（1996年4月26日受理）

\section{Oxygen Adsorption on Si (001) Surface}

Toshihiro UCHIYAMA

Advanced Materials Research Laboratory, Matsushita Research Institute Tokyo, Inc.

3-10-1 Higashi-mita, Tama-ku, Kawasaki 214

(Received April 26, 1996)

超1 Gbit級の半導体デバイスの実現に向けて, シリコン半導体表面の酸化反応を原子レベルで制御し, 絶縁 性の高い極薄（膜厚 $3 \mathrm{~nm}$ 以下の）酸化膜を形成する技術が必要となりつつある。このためには，シリコン表 面における酸化反応の原子過程やその機構などを包括的に理解することが不可欠である。ここでは, $\mathrm{Si}(001)$ 表面の初期酸化過程で期待される酸素原子の吸着構造を中心に，その第一原理計算による最近の研究を紹介す る。特に, 走査型トンネル顕微鏡を用いた, 酸素吸着による表面構造変化の観察方法について議論する。

\section{1. は じめに}

次世代の半導体デバイス技術において解決すべき大き な課題の一つとして,「ゲート酸化膜の薄膜化とその膜 質の向上」がある。いわゆるMOSトランジスタの比例 縮小則 ${ }^{1)}$ によれば，21世紀初め（2004年）には素子密度 は1 Gbitに到達し, ゲート酸化膜厚は4 5 nmになること が予測されている。この膜厚は， $\beta$-クリストバライト $\left(\mathrm{SiO}_{2}\right)$ 結晶では約 25 原子層に相当する。一方, 酸化膜 には電極と基板間にリーク電流が流れないように，高い 絶縁性が必要である。この為には酸化膜の薄膜化と同時 に, $\mathrm{SiO}_{2} / \mathrm{Si}$ 界面の平滑化, サブオキサイド $\left(\mathrm{SiO}_{x}, x=\right.$ 1 3）の除去, 構造転移層の低減などが求められる。

この課題の解決に向けて, シリコン表面の酸化反応を 原子レベルで制御する技術が強く望まれる。この理由か ら, 近年, 半導体表面の酸化過程の研究が様々な角度か ら行われている ${ }^{2)}$ 。例えば，走查型トンネル顕微鏡 （STM）などの観察技術の発展により, 初期酸化過程に おけるシリコン表面の原子スケールの実像が得られるよ うになった ${ }^{3 \sim 5)}$ 。しかし, 酸化反応の原子過程や機構, 形成された酸化物の原子構造など, 未だほとんど理解さ れていない。それらを解明することが，原子レベルで酸
化過程を制御することへの第一歩となる。この解明に当 たって，第一原理的な理論計算によりシリコン表面にお ける酸素原子・分子の挙動をシミュレーションすること は, 非常に重要かつ有力な研究方法である。そのような 研究が，従来実験サイドから提唱されてきた様々な模型 の妥当性を検証し, 酸化過程の包括的な描像を確立する 一助となることが期待される。

そこでこの解説記事では, Si(001) 表面の初期酸化過 程で期待される酸素原子の吸着構造を中心に, その第一 原理計算による最近の研究を紹介する。周知のように, （001）面はほとんどのシリコンデバイスで用いられる結 晶面である。

\section{2. 最近の理論研究について}

最近の理論物性物理学の中で, 擬ポテンシャル法を用 いた密度汎関数形式の電子状態計算は, 最も信頼性の高 い計算手法の一つである。その著しい進歩は近年の計算 機能力の向上と相まって, 目覚しい成果を上げている。 特に今日では，第一原理的に原子に働く力を計算しそれ に従って各原子を動かすことで, 系の構造予測まで可能 となりつつある。

このような計算手法を $\mathrm{Si}(001)$ 面上の酸素分子・原子 
の挙動の記述に初めて適用したのが, 宮本・押山 ${ }^{6,7)}$ で ある。従来この系では, クラスターを用いた量子化学的 計算か, 薄膜模型を用いた半経験的強束縛計算が主で, 表面のダイマー構造はほとんど考虑されていなかった ${ }^{8)}$ 。 宮本・押山は, 酸素原子の局在する価電子軌道を取り扱 うために，ガウス型関数基底を導入した。これにより， 通常の平面波基底では数值計算を実行する上で基底の数 が大きくなり過ぎる難点を回避できる。しかし，基底関 数が原子座標に依存するため原子に働く力の計算が複雑 になり,さほど計算時間・コストの削隇には镃がらな い。

宮本・押山は，この第一原理計算で, $\mathrm{Si}(001)$ 再構成 表面では酸素原子に対して三つの異なる吸着サイトが存 在することを見出した。（各吸着サイトの構造について は, 第4節で議論する。）さらに，彼らは同表面におけ る酸素分子のエナジェティクスから, 酸化の初期過程に 関する幾つかの興味樑い議論を行っている。例えば, 酸 素分子はサイトに依らず, 表面に近付くにつれて自然と 解離すること。一原子層以上酸化が進むためには表面内 部に酸素分子が侵入しなければならないが，エネルギー 障壁が存在しその過程は低温では起こらないことなどで ある。

一般的に, 酸素に代表される周期律表第一列原子を含 む系の第一原理計算は容易ではない。それを充分可能な らしめたのが, Vanderbiltが提唱した超ソフト擬ポテン シャル法" ${ }^{9}$ の導入である。この擬ポテンシャル法では電 荷密度から原子核近傍に局在する成分を分離し, 残りの 滑らかに变化する部分だけを擬波動関数に担わせるもの である。これにより, 平面波基底の数を数值計算が実用 上可能な程度に抑えることができる。最近この手法を用 いた第一原理計算が盛んに行われるようになり，それに 伴って $\mathrm{Si}(001)$ 面と酸素の系にも応用されるようになっ た。

そこで以下の節では, この第一原理計算法を用いた, Si (001) 面における酸素原子の吸着構造とSTMによるそ の同定法に関する最近の研究 ${ }^{10)}$ を紹介する。

\section{3. 理論計算の方法}

この節では, 超ソフト擬ポテンシャル法に拠る第一原 理分子動力学法の要点をまとめる。詳細については, 論 文 ${ }^{10)}$ を参照されたい。

酸素原子に対してカットオフ半径 $r_{c}=1.3$ a.u.の超ソフ ト型9), シリコン原子に対して $r_{c}=1.6$ a.u.のノルム保存 型擬ポテンシャル ${ }^{11)}$ を用いる。また, 交換相関ポテンシ ヤルにはCeperley-Alderの表式 ${ }^{12)}$ を使った。そして, 波 動関数を展開する平面波基底のエネルギーカットオフは
$E_{\mathrm{cut}}=25 \mathrm{Ry}$ に設定した。

一方 $\mathrm{Si}(001)$ 表面として, シリコン八原子層の薄膜と 四原子層相当の厚さの真空から成る repeated slab模型を 用いる。表面単位胞は $2 \times 1$ の大きさに取る。また, 表 面に平行な適当な軸に対して, 系は $180^{\circ}$ 回転対称性を有 するものとする。酸素原子を導入する時もこの対称性を 維持して, 薄膜の二つの表面の同等な位置に酸素原子を 置く。ブリルアン域の運動量積分には, 八点のサンプル $k$ 点を用いた。

ある原子配置において個々の原子に働く力は, 全エネ

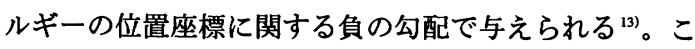
の原子間力に従って共役勾配法 ${ }^{14)}$ に拠り，原子位置の最 適化（エネルギーが極小となる原子位置の探索）を行っ た。ここでは, すべての原子に颠く力の大きさが $3 \times$ $10^{-3}$ Hartree/a.u.以下となった時, 収束と判定した。

最後に, STMのトンネル電流 $I\left(r, V_{\mathrm{s}}\right)$ を

$$
I\left(r, V_{\mathrm{s}}\right) \propto \pm \int_{E_{\mathrm{F}}}^{E_{\mathrm{F}}+e V_{\mathrm{s}}} d E \rho(r, E)
$$

と近似する。ここで, 複号（土）は表面バイアス電圧 $V_{\mathrm{s}}$ の符合を取るむのとする。 $E_{\mathrm{F}}$ はフェルミエネルギー, $\rho(r, E)$ は位置 $r$, エネルギーEにおける局所状態密度で ある。このトンネル電流の表式では探針の原子構造や電 子状態の効果は考慮されていないが，定性的な議論には これで十分である。

\section{4. $\mathrm{Si}(001)$ 面における酸害吸着の原子構造}

初めに, $\mathrm{Si}(001)-2 \times 1$ 表面の原子構造を最適化する。 その結果, 安定な非対称ダイマー構造が得られた。その 構造を図1(a) に, 得られたダイマーのボンド長とその 傾きを衰 1 に示す。ここで，ダイマーの下側原子が成す 三本の結合は $s p^{2}$ 的でかなり平面性が高い。また，その バックボンドは第二層原子から見ると正四面体の向きか ら大きくずれており，大きな歪み（応力）が惩かってい ると考えられる。

次に, この $\mathrm{Si}(001)$ 面上に酸素原子を導入し, 安定な 吸着サイトとその原子構造を探索した。ただし, 酸化の 初期過程を念頭に置いているので, 表面第二層より内部 に酸素原子が入ることは考虑していない。そのような吸 着を扱うためには, もっと大きな表面単位胞を用いる必 要がある。

その結果, 次の五つの (準) 安定なサイトを見い出し た。
๑ダイマーブリッジ（DB）
○ダイマーの真上（OD）
○上側ダイマー原子のバックボンド (BBu)
○下側ダイマー原子のバックボンド（BBd） 
a)

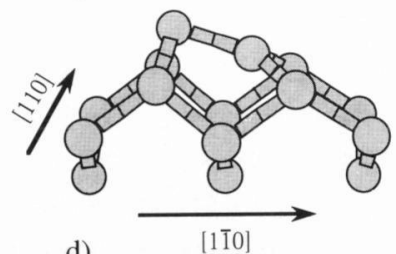

d)

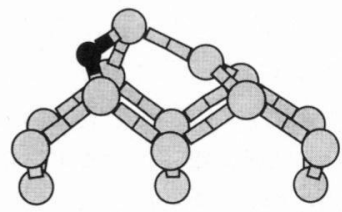

b)

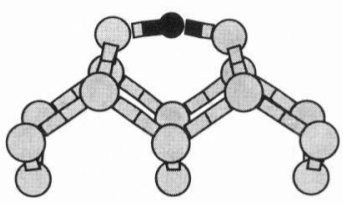

e)

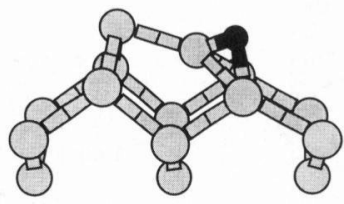

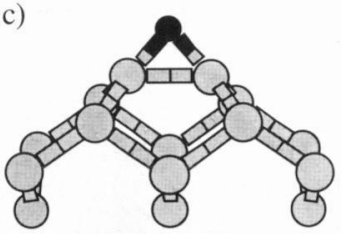

f)

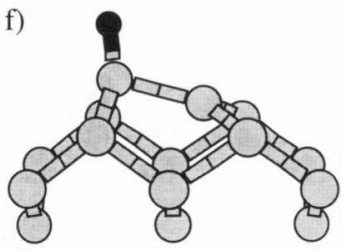

图 1 Si (001)表面における酸素原子の吸着構造。(a) Si (001)清浄表面と(b) DBサイト, (c) ODサイト, (d) BBuサイト，(e) BBdサイト，(f) Tサイトへの吸着構造。は酸素原子を表す。

表 $1 \mathrm{Si}(001)$ 面における酸素原子吸着の構造パラメータ。各吸着構造に対して, Si-O 結合長 $d_{\text {Si- }}$, 酸素原子の結合角 $\theta_{0}$, ダイマー結合長 $d_{\mathrm{si} \text { si }}$ とその傾き $\phi_{\mathrm{si} \text { is }}$ を示す。ここで, $\phi_{\mathrm{si} \text { - i }}$ は, ダイマ 一結合と[1ㅣㅣㅇㅣ方向のなす角度で定義した。また, ダイマーあたりのエネルギーを, 最安定 なBBdサイトを基準にして与えた。

\begin{tabular}{ccccccc}
\hline & $\mathrm{Si}(001)$ & $\mathrm{DB}$ & $\mathrm{OD}$ & $\mathrm{BBu}$ & $\mathrm{BBd}$ & $\mathrm{T}$ \\
\hline$d_{\text {si-o }}(\AA)$ & & $1.63,1.63$ & $1.70,1.70$ & $1.67,1.63$ & $1.63,1.69$ & 1.53 \\
$\theta_{\mathrm{o}}$ & & $161^{\circ}$ & $81^{\circ}$ & $124^{\circ}$ & $103^{\circ}$ & \\
$d_{\text {Si-Si }}$ & 2.28 & & 2.20 & 2.33 & 2.28 & 2.39 \\
$\phi_{\text {Si-Si }}$ & $19^{\circ}$ & & $0^{\circ}$ & $28^{\circ}$ & $17^{\circ}$ & $17^{\circ}$ \\
エネルギー $(\mathrm{eV})$ & & 0.12 & 0.15 & 0.48 & 0. & 1.29 \\
\hline
\end{tabular}

-上側ダイマー原子の上（T)

その原子構造を, 図1(b) から図1(f) に示す。また, 幾 つかの構造パラメータを表 1 にまとめる。Si-O 結合長 $d_{\text {si-o }}$ と酸素原子の結合角 $\theta_{0}$ は, シリカ $\left(\mathrm{SiO}_{2}\right)$ 結晶（高圧相 のスティショバイトを除く。) の対応する值 ${ }^{15)}, 1.52$ $1.69 \AA, 137^{\circ} \sim 180^{\circ}$ と矛盾しない。ただし, ODサイト では結合角が $81^{\circ}$ とかなり小さいが，これはл結合性が 強いダイマー結合を形成するためと考えられる。酸素が 吸着したダイマーはサイトに依存して, 結合が切断され たり (DBサイト), ダイマー列の向きに捻れたり (BBu, BBdサイト) する。

DBサイト（図1(b)) では, ダイマー結合が切断され てそこに酸素原子が捰入され。この吸着で, ダイマー 原子のバックボンドに懸かっていた歪みは大きく解消さ れる。一方 ODサイト（図1(c)) では, ダイマー結合が 維持されたまま酸素原子はその真上に吸着する。いずれ の場合も, 形成された Si-O-Si構造は対称的である。し かし, 電子構造は二つのサイトで大きく異なる。DBサ イトへの吸着では, 元々ダイマーを形成していたシリコ ン原子がダングリングボンドを残しているので，金属的
である。これに対し ODサイトの吸着構造では, ダイマ 一原子の三本の結合, 酸素原子との結合と二本のバック ボンド, が成す結合角の和はほぼ $360^{\circ}$ で $s p^{2}$ 性が非常に 強い。そして, 残りの $p$ 軌道が $\pi$ 結合しダイマーを形成 する。したがって, ODサイトは半導体的である。この ようにそのダイマー結合は, 清浄面（主に $\sigma$ 結合で， $\pi$ 結合性を併せ持つ。）とは性格が大きく異なっている。

$\mathrm{BBu}$ サイト（図1(d)) では, 酸素原子が上側のダイマ 一原子を大きく持ち上げて，第二層原子との間に割り込 む構造を取る。これに対して, BBdサイトへの吸着（図 1(e)）は次のような構造上の特徴を示す。第一に, ダイ マーの結合長や傾きは, 酸素吸着によりさほど变化しな い（表 1 参照）。第二に，その下側原子の三本の結合は $s p^{2}$ 的で, 清浄面と同じく平面性が高い。ただし, その 結合の作る平面は, ダイマ一結合の周りに少し回転して いる。これに伴って, 下側原子のダングリンダボンドも ダイマー列の向きに傾く。その様子を図 2 に示す。第三 に, 酸素原子が挿入されることでバックボンドの歪みが 解消している。(もう一本のバックボンドは残っている が。）いずれのバックボンドサイトでもダイマー結合が 


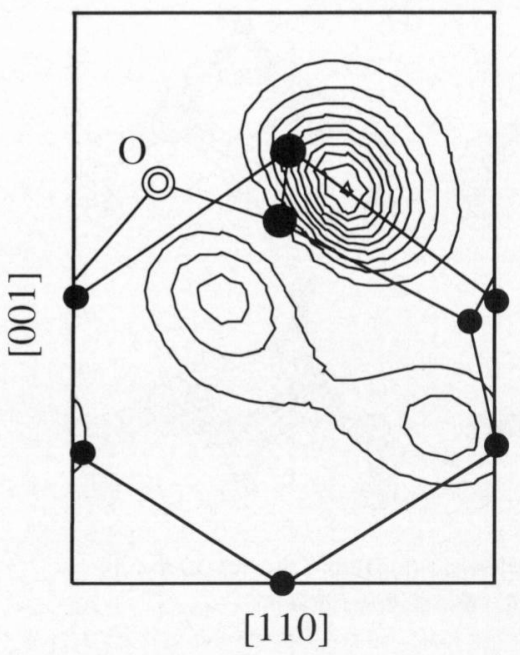

図2 $\mathrm{BBd}$ サイトでの酸素原子の吸着構造と下側ダイマー原子の ダングリングボンド(非占有状態)。ブリルアン域の $K$ 点に おけるバンドの波動関数(絶対值の二乗)を, 下側ダイマー 原子を含みダイマーに平行な面((11̄0)面)で, 等高線表示し ている。は酸素原子, はシリコン原子の位置を示す。

保持されているので, $\mathrm{BBu}, \mathrm{BBd}$ サイトは半導体的にな る。

上記の四つの吸着サイトの中で, 最もエネルギー的に 安定であるのはBBdサイトであった。高分解能電子エネ ルギー損失分光の測定では, まさにバックボンドに酸素 が入ることが報告されている ${ }^{16)}$ 。のサイトを基準にし て, 各吸着構造のエネルギーを表 1 によぬる。それに よると，BBdサイトとDB，ODサイトのエネルギー差 は $\leq 0.15 \mathrm{eV}$ と小さく, この三つの吸着構造が共存する ことも考えられる。

ところで, $\mathrm{DB}, \mathrm{OD}, \mathrm{BBd}$ サイトの各吸着構造は, 宮 本・押山 ${ }^{6)}$ が得たものと符合する。ただし彼らの計算で は, BBuサイトに対応する構造は得られていない。これ は, 同サイトが吸着エネルギー面の浅い極小であること が原因と推察される。また, 彼らは OD, BBdサイトで, $1.9 \AA$ と非常に長いSi-O 結合を与えている。さらに, 我々の計算結果との最も重要な違いは, 吸着サイトのエ ネルギー安定性である。宮本・押山の計算ではDBサイ トが最安定であり，BBdサイトはそれに比べて $1.4 \mathrm{eV}$ ほ どエネルギー的に不利である。この違いの一因は，表面 構造の最適化の過程にある。すなわち, 彼らは基板第二 層以下の原子をバルク位置に固定したまま, ダイマー原 子と酸素原子の位置だけを最適化した。この制限を課す と, 我々の計算でも DBサイトがわずかに BBdサイトよ り安定になった。

ここまで議論してきた四つの吸着サイトでは, いずれ
も酸素原子が Si-O-Si 結合を形成して安定化する。これ と異なった機構により，酸素が吸着することがある。そ れが, 図1(f) に示した Tサイトへの吸着である。この 吸着構造では, Si-O結合は一見一重に見えるがその長さ は $1.53 \AA$ (表 1 参照。) と短く, $\mathrm{SiO}$ 分子の結合長（1.51 Å)に近い。一方ダイマー結合は，清浄面と比較して約 $0.1 \AA$ 伸びている。また Si-O結合の波動関数を調べてみ ると, $\mathrm{SiO}$ 分子の結合の内二重に縮退した $\pi$ 軌道まで占 有された状態になっていることがわかる。すなわち, T サイトの Si-O 結合は二重結合的である。かつて, Ludeke ・ 小間 ${ }^{17)}$ は低速電子エネルギー損失分光スペクト ルから，酸素原子は二重結合を形成して表面に吸着する ことを議論している。一方, $\mathrm{SiO}$ 分子の結合の $\sigma$ 軌道か ら成るバンドは空である。何らかの理由で, シリコン原 子のバックボンドからそのバンドに電子が移れば, $\mathrm{SiO}$ が分子として離脱することが期待される。それは, 酸素 による表面のエッチングにほかならない。

Tサイトへの吸着は準安定であるが，表1からわかる ようにエネルギー的には他のサイトに比べて非常に不利 である。それほど大きくはないエネルギー障壁を越えて, 他のより安定なサイトに酸素原子が移って行くことは十 分期待できる。したがって, このTサイトへの吸着構造 は, $\mathrm{SiO}$ 分子形成によるエッチングか, 酸化物形成によ る膜成長かの分岐点であると考えられる。

\section{5. $\mathrm{Si}(001)$ 面における酸素吸着の走查型トン ネル顕微鏡像}

走查型トンネル顕微鏡（STM）は，試料表面の原子ス ケールの実像を得ることができるという大きな利点を持 っている。それゆえ, シリコン表面の初期酸化過程のよ らな局所的な構造变化を研究するには, 最適な観察手段

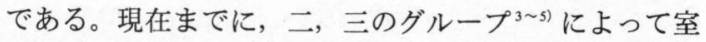
温酸化の観察に応用されているが, 酸化物の構造を解明 するまでには至っていない。そこでこの節では, 前節で 得られた酸素原子の吸着構造が与えるSTM像をシミュ レーションし，それらを同定するための一助としたい。

$\mathrm{Si}$ (001) 清净面と DB，BBd，ODサイトの酸素吸着の STM像を, 図3に示す。表面バイアス電圧は, 左側の列 では $V_{\mathrm{s}}=-1 \mathrm{eV}$ (占有状態像), 右側の列では $V_{\mathrm{s}}=+1$ $\mathrm{eV}$ (非占有状態像) に設定した。また, 探針の走查面は 表面から $2.3 \AA$ の高さで, すべての薄膜模型で共通であ る。図ではトンネル電流の大きさを対数スケールで濃淡 表示しており, そのスケールは各バイアスごとに設定さ れている。白丸は酸素原子, 斜線付きの丸は最外層シリ コン原子の位置を示す。

清浄表面のSTM像（図3(a)）では, ダイマーの上側 
a)

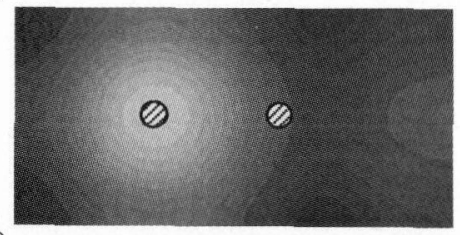

b)
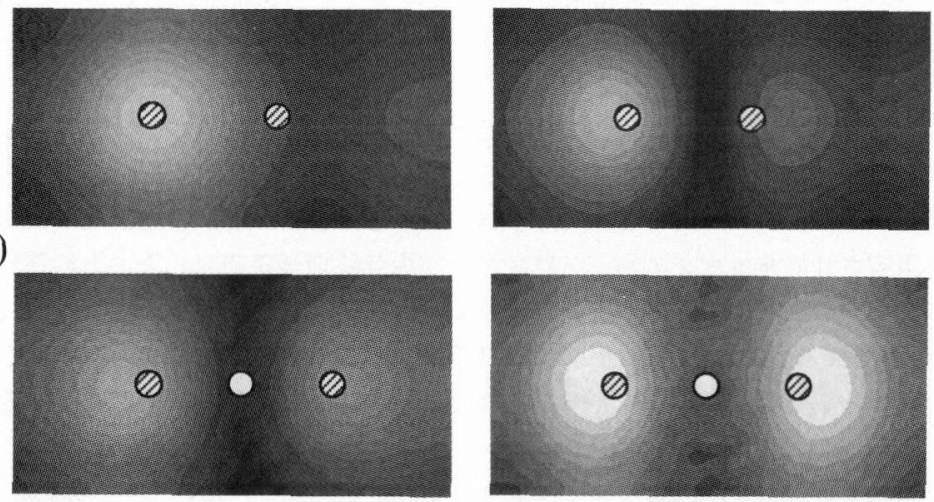

c)
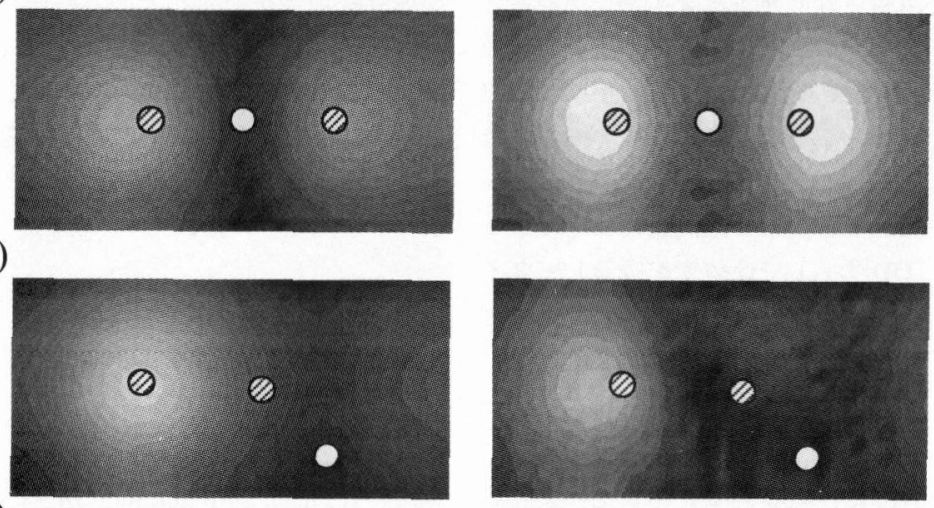

d)
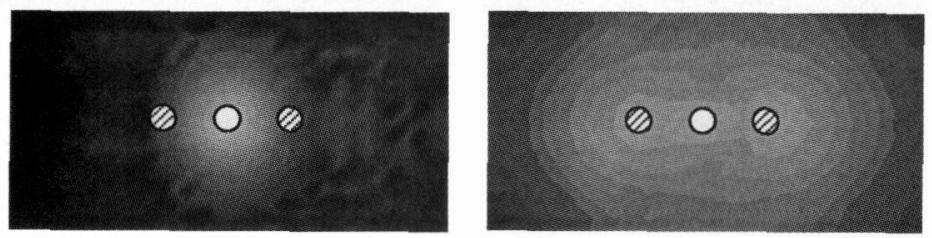

図3 Si (001)表面における酸素原子吸着のSTM像。(a) Si (001)表面と，(b) DBサイト，(c) BBdサイト, (d) ODサイトへの吸着構造の像。表面バイアス電圧は, $V_{\mathrm{s}}=-1 \mathrm{eV}$ (左 側の列 ; 占有状態像)と $V_{\mathrm{s}}=+1 \mathrm{eV}$ (右側の列 : 非占有状態像)である。探針の走查面 は, 表面から $2.3 \AA$ の高さである。ここでは, トンネル電流の大きさを対数スケー ルで濃淡表示している。そのスケールは, 各バイアス電圧ごとに設定した。○は酸 素原子, ○は最外層のシリコン原子の位置を示す。

原子が常に明るく見えるのに対して，下側原子は非占有 状態像でのみやや暗いスポットとして観察できる。

酸素原子は吸着サイトに依存して, このSTM像を変 化させる。DBサイト（図3(b)) では，元々ダイマーを 形成していた二つのシリコン原子が，表面バイアスの極 性とは無関係に明るく見える。これは, そのシリコン原 子がダングリングボンドを残しているからである ${ }^{18)} 。 一$ 方, BBdサイトのSTM像（図3(c)）は清浄面のそれと 良く似ている。これは, ダイマー結合が保持されている ことの反映である。ただし, 詳細に見ると次のような違 いが見受けられる。第一に占有状態像では, ダイマーの 上側原子がやや明るくなる。これは, 上側原子が少し (0.1 ^程度) 持ち上げられること,ダイマー原子間の電 荷移動が酸素原子により促進されること, の二つが原因 である。第二に非占有状態像では，下側原子による暗い スポットがダイマー列の向きにずれている。これは, 図
2に示したようにダングリングボンドが傾いたからであ る。

上記の二つのサイトでは, 酸素原子を直接 STM で捕 らえることはできない。これに対して，ODサイト（図 3(d)）に吸着した酸素原子は, 占有状態像で観察するこ とができる。これは, 酸素原子が表面から大きく外側に 張り出しているからである。ここで, 酸素原子はダイマ 一原子から $1.3 \AA$ の高さに位置している。また, 非占有 状態像ではダイマー全体がぼんやりと見えている。

今までのSTM観察では，DB，ODサイトへの吸着を示 唆する像は報告されていない。これに対して, Klieseら は, 酸化の極初期段階で占有状態像に小さな突起物が現 れることを観察している。この突起物は $0.2 \AA$ の高さで, ダイマー列間のブリッジサイトに生ずる。これは, BBd サイトの特徴と良く符合する。しかし, 彼らも非占有状 態像は得ていない。 
ここで示したSTM像のシミュレーション結果を実際 の観察像と比較する際に, 注意すべきことがある。それ は, ダイマーの反転振動である。Wolkow ${ }^{19)}$ と杤原ら ${ }^{20)}$ は低温のSTM観察から, 室温では非対称ダイマーが反 転振動していて，時間平均として見かけ上対称的になる ことを示した。ただし，ダイマーの欠落点など欠陥の周 辺では，その振動が阻害されて非対称ダイマーが観察さ れる。このようなダイマーの反転振動があると, 酸素吸 着のSTM像はどう変わるであろうか。BBdサイトの周 辺では，二つのバックボンドサイトのエネルギー差を考 えると, ダイマーの傾きは固定されるであろう。Kliese らの観察した小さな突起物の周りでは, まさにそうなっ ている。一方, DB, ODサイトでは酸素が吸着したダイ マーは対称的になるが，これが周りのダイマーの振動に 与える影響については今後の検討課題である。

\section{6. まと加}

以上, $\mathrm{Si}(001)$ 表面における酸素吸着の安定構造とそ のSTM像に関する最近の理論研究を紹介した。図1に示 したように, 酸素原子に対して多様な吸着サイトが存在 し得る。その中で, BBdサイトが最もエネルギー的に安 定である。このサイトをSTMで同定するには，次のよ うにすれば良い。まず負の表面バイアス電圧（占有状態 像）で，周りのダイマーより上側原子が少し明るく見え ている简所を探す。その周りでは, ダイマーの傾きが固 定されているであろう。次に, 同じ場所を正のバイアス 電圧（非占有状態像）で観察する。この時, 下側原子に よる暗点がダイマー列の向きにずれているかどうかが鍵 である。

つい最近池上ら ${ }^{21)}$ は，STM と走㚗型トンネル分光法 （STS）による興味深い研究結果を報告している。それ によると, 酸化後も STMで $2 \times 1$ 構造が観察される領域 で，STS スペクトルの測定から酸素原子がバックボンド に吸着していることがわかったという。この観察は, 我々の計算結果（BBdサイトへの吸着）と非常に良く符 合する。

このように酸素吸着による幾つかの安定構造が明らか になったが，シリコン表面の酸化反応を原子レベルで理 解するにはまだ多くの課題が残されている。当面の課題 として,

。酸素原子の吸着過程とバルク中への拡散。例えば, Tサイトからより安定なサイトへの酸素原子の移動 ○酸素分子の解理吸着とその機構

の解明が必要であろう。また，現実のシリコン表面には 多くの欠陷やステップが存在し, 酸化の起点となること が知られている ${ }^{4,5)}$ 。したがって，このような欠陥やス
テップでの反応解析も必要である。最近, JRCATの宇田 ら ${ }^{22,23)}$ により, 酸素分子の解理吸着と原子状欠陥の構造 解析が精力的になされていることを付記して置く。

\section{謝辞}

この解説で紹介した研究は，塚田 捷教授（東京大学 大学院理学研究科）との共同研究に基づくものである。 ここで，塚田教授に厚く謝意を表したい。また，渡辺 聡氏, 山内 淳氏には理論計算に際して大変お世話にな った。ここで，両氏に深く感謝致します。なお図 1 を描 くに当たり, ミネソタ大学スーパーコンピューターセン ターで開発されたXMol（version 1.3.1）を用いている。

\section{立献}

1) B. Davari and R.H. Dennard: 日経マイクロデバイス 1994年9月号, p. 142.

2) 酸素原子・分子とシリコン表面の相互作用に関する 良いレビュー記事として,

T. Engel: Surf. Sci. Rep. 18, 91 (1993).

3) P. Kliese, B. Röttger, D. Badt and H. Neddermeyer: Ultramicroscopy 42-44, 824 (1992).

4) Ph. Avouris and D.G. Cahill: Ultramicroscopy 42-44, 838 (1992),

D.G. Cahill and Ph. Avouris: Appl. Phys. Lett. 60, 326 (1992),

Ph. Avouris and I.-W. Lyo: Appl. Surf. Sci. 60/61, 426 (1992).

5) M. Udagawa, Y. Umetani, H. Tanaka, M. Itoh, T. Uchiyama, Y. Watanabe, T. Yokotsuka and I. Sumita: Ultramicroscopy 42-44, 946 (1992).

6) Y. Miyamoto and A. Oshiyama: Phys. Rev. B \$1, 12680 (1990),

Y. Miyamoto, A. Oshiyama and A. Ishitani: Solid State Commun. 74, 343 (1990).

7) Y. Miyamoto and A. Oshiyama: Phys. Rev. B 43, 9287 (1992).

8) ダイマー構造を考虑したクラスター計算として, P.V. Smith and A. Wander: Surf. Sci. 219, 77 (1989), X.M. Zheng and P.V. Smith: Surf. Sci. 232, 6 (1990).

9) D. Vanderbilt: Phys. Rev. B 41, 7892 (1990).

10) T. Uchiyama and M. Tsukada: Phys. Rev. B 53, 7917 (1996).

11) N. Troullier and J.L. Martins: Phys. Rev. B 43, 1993 (1991).

12) D.M. Ceperley and B.J. Alder: Phys. Rev. Lett. 45, 566 (1980).

13) K. Laasonen, A. Pasquarello, R. Car, C. Lee and D. Vanderbilt: Phys. Rev. B 47, 10142 (1993).

14) W.H. Press, B.P. Flannery, S.A. Teukolsky and W.T. Vetterling: "Numerical Recipes" (Cambridge University Press, 1986).

15) R.W.G. Wyckoff: “Crystal Structures”, 2nd ed. (Interscience, New York, 1965).

16) J.A. Schaefer, F. Stucki, D.J. Frankel, W. Göpel and G.L. 
Lapeyre: J. Vac. Sci. Technol. B 2, 359 (1984),

J.A. Schaefer and W. Göpel: Surf. Sci. 155, 535 (1985).

17) R. Ludeke and A. Koma: Phys. Rev. Lett. 34, 1170 (1975).

18) Y. Miyamoto: Phys. Rev. B 46, 12473 (1992).

19) R.A. Wolkow: Phys. Rev. Lett. 68, 2636 (1992).

20) H. Tochihara, T. Amakusa and M. Iwatsuki: Phys. Rev.
Lett. 50, 12262 (1994).

21) H. Ikegami, K. Ohmori, H. Ikeda, H. Iwano, S. Zaima and Y. Yasuda: Jpn. J. Appl. Phys. 35, 1593 (1996).

22) T. Uda: Proc. '95 JRCAT Int. Symp. on Nanoscale Self Organization, 1995, p.21.

23) T. Uda and K. Terakura: Phys. Rev. B 53, 6999 (1996). 